\title{
STRUKTUR MAKAM K.H. TUBAGUS LATIFUDDIN PAGERAJI, KABUPATEN MAJALENGKA
}

\author{
U. Abdul Syukur \\ PUI Cabang Bongas Indramayu (u.a.syukur45@gmail.com)
}

\begin{abstract}
Majalengka is an area in Tatar Sunda that has a long history. This area has even been the basis of a number of kingdoms that once existed in the history records of our nation. When Islam began to spread to Parahyangan area from Cirebon direction, some areas did not immediately accept the religion which came from the Arab land. Two of them are Talaga and Rajagaluh which are located exactly in Majalengka Regency now. The situation is certainly raises many questions considering the current regency is inhabited by the majority of Muslims. Of course one of the things that make it curious is about the gait of the spreaders of Islam in the community. One of the spreaders of Islam in Majalengka is K.H. Tubagus Latifuddin residing in Pageraji. From oral tradition it is known that this charismatic figure has a very significant role to increase the number of adherents of Islam in the area. His very special positioning of his grave shows that K.H. Tubagus Latifuddin is not an arbitrary person, because he still has a permanent place in the heart of society even though this character has long died.
\end{abstract}

Keywords: tombs, the spread of Islam, community leaders, Majalengka

\begin{abstract}
Abstrak
Majalengka adalah sebuah daerah di tatar Sunda yang memiliki perjalanan sejarah yang panjang. Daerah ini bahkan pernah menjadi basis dari sejumlah kerajaan yang dulu pernah eksis dalam catatan sejarah bangsa kita. Ketika Islam mulai menyebar ke daerah Parahyangan dari arah Cirebon, beberapa wilayah tidak serta merta menerima agama yang berasal dari tanah Arab tersebut. Dua di antaranya adalah Talaga dan Rajagaluh yang letaknya persis di wilayah Kabupaten Majalengka sekarang. Keadaan itu tentunya memunculkan banyak pertanyaan mengingat saat ini kabupaten tersebut dihuni oleh mayoritas umat Islam. Tentu salah satu hal yang membuat penasaran itu adalah mengenai kiprah para penyebar Islam di tengah masyarakat. Salah satu penyebar Islam di Majalengka adalah K.H. Tubagus Latifuddin yang bertempat tinggal di Pageraji. Dari tradisi lisan diketahui bahwa sosok kharismatik ini memiliki peran yang sangat signifikan terhadap peningkatan jumlah penganut Agama Islam di daerah tersebut. Pemosisian makamnya yang sangat khusus pun menunjukkan bahwa K.H. Tubagus Latifuddin bukanlah orang sembarang, karena tetap memiliki tempat yang permanen di tengah hati masyarakat meskipun tokoh ini sudah lama tiada.
\end{abstract}

Kata Kunci: Makam, penyebaran Islam, tokoh masyarakat, Majalengka

\section{A. Pendahuluan}

Salah satu doktrin sejarah yang mungkin terus dianut oleh para peserta didik (dan mungkin juga masyarakat umum) adalah bahwa agama Islam baru masuk ke Indonesia pada abad ke13 saat perniagaan dengan orang-orang Gujarat India tengah mencapai
puncaknya. Ajaran yang juga bisa
disebutkan sebagai mitos tersebut, sengaja disebarluaskan oleh para orientalis yang memang tidak menginginkan sejarah Islam Indonesia diungkap secara lengkap. Salah satu sosok orientalis yang dimaksud adalah Snouck Hurgronje yang memang tidak mengakui bahwa Islam masuk ke Nusantara jauh lebih awal. Pendapat ini patut dipertanyakan tendensinya karena memang sangat mengabaikan pelbagai 
fakta, bukti dan penelitian yang dijabarkan oleh para ahli-ahli sejarah mengenai kemungkinan masuknya Islam ke Indonesia lebih awal. ${ }^{1}$

Meskipun Islam telah datang ke bumi Nusantara lebih dulu dari perkiraannya, namun eksistensinya baru sebatas di sejumlah kecil daerah saja. Bahkan mungkin bisa dikatakan hanya di beberapa daerah pesisir pantai, seperti di sekitar Aceh dan Sumatera Utara. Hal itu menunjukkan bahwa pada mulanya Islam berkembang dengan sangat lambat di tengah masyarakat, dan kemajuannya yang pesat baru dapat dilihat beberapa abad kemudian, ketika pengembangan Islam mulai dirintis oleh para ulama dan sufi yang menyentuh dengan baik sisi-sisi kultural masyarakat.

Para alim ulama dan sufi yang tidak henti-hentinya mensyiarkan Islam di tanah Jawa, umumnya selalu dinisbatkan kepada sosok-sosok yang dikenal sebagai Wali Sanga (Wali Sembilan). Perkembangan itu semakin pesat, terutama ketika Islam sudah terinstitusionalisasikan ke dalam wujud kekuasaan. Institusi-insitusi Islam yang

1 Mengenai diskursus ini, lihat lebih lanjut, Moeflich Hasbullah, Sejarah Sosial Intelektual Islam Indonesia, (Bandung: Pustaka Setia, 2011), hal. 1-12. ada di Jawa, berbasis di Cirebon, Banten, Demak dan Mataram. ${ }^{2}$

Di tanah Pasundan, proses Islamisasi baru datang kemudian setelah gerakan itu timbul sebelumnya di bumi Jawa. Tokoh-tokoh penting yang menjadi penyebar awal Islam di wilayah yang kemudian menjadi Jawa Barat ini adalah para keturunan Raja Sunda Prabu Siliwangi, yaitu Pangeran Cakrabuana (Walangsungsang) dan Raden Syarif Hidayatullah (Sunan Gunung Jati). Sejumlah naskah tradisional, juga menyebutkan nama Prabu Kian Santang, yang juga merupakan keturunan dari Sri Baduga Maharaja. Di antara ketiganya, tokoh penyebar Islam terpenting dan yang paling banyak disebutkan dalam tradisi lisan dan juga sejumlah manuskrip adalah Syarif Hidayatullah. Pusat pengembangan Islam yang dirintis oleh tokoh ini terletak di Cirebon.

Syarif Hidayatullah, atau yang masyhur dengan nama Sunan Gunung Jati, mendakwahkan Islam secara damai ke pelbagai daerah di Jawa Barat. Meskipun demikian, nyatanya tidak semua wilayah yang dekat dengan Cirebon itu dapat di-Islamkan

\footnotetext{
2 Edi S. Ekadjati, "Sundanese Manuscripts: Their Existence, Functions, and Contents", Journal of the Centre for Documentation \& AreaTranscultural Studies, 2 (2003), hal. 129.
} 
dengan mudah. Daerah Rajagaluh dan Talaga misalnya, baru menyatakan diri berada di bawah kekuasaan Cirebon pada tahun 1528 dan $1530 .{ }^{3}$ Dengan demikian, wilayah yang saat ini masuk ke dalam daerah Majalengka itu menunjukkan bahwa proses Islamisasi di barat Ciremai itu tidak semudah yang dipikirkan.

Sebelum berkembangnya agama Islam, daerah-daerah yang sekarang menjadi Majalengka itu memang berada dalam kekuasaan Kerajaan Sunda-Galuh. Kerajaan ini sendiri ditengarai banyak ahli sejarah sebagai kerajaan yang menganut corak keagamaan Hindu dan Buddha. Walaupun demikian, ada pula yang meyakini bahwa kerajaan terbesar masyarakat Sunda itu memiliki kepercayaan lokal yang khas, yaitu Agama Jatisunda. Dalam perkembangan selanjutnya, wilayahwilayah itu berubah menjadi daerah yang menganut agama Islam, terutama setelah Sunan Gunung Jati beserta murid-muridnya melancarkan dakwah ke pelbagai tempat di Tatar Sunda, termasuk ke daerah-deaerah Majalengka.

3 F. de Haan, Priangan: De PreangerRegentschappen onder het Nederlandsch bestour tot 1811 (Batavia: G. Kolff/Martinus Nijhoff, 1912), hal. 33-41.
Sebagaimana

diuraikan

sebelumnya, terdapat hal yang tidak biasa dalam proses Islamisasi Majalengka. Berbeda dengan kegiatan peng-Islaman di Luragung atau Kuningan, yang berjalan dengan damai dan tanpa adanya hambatan yang berarti, di Majalengka para pendakwah Islam harus terlebih dahulu melakukan sejumlah peperangan dengan elit-elit lokal yang memobilisasi masyarakat setempat untuk melawan orang-orang Islam yang saat itu dikirim dari Cirebon, Banten dan Demak.

Dalam beberapa naskah Babad Cirebon, diketahui bahwa dua wilayah di Majalengka yang dalam perkembangan Islam awal selalu melakukan resistensi adalah Rajagaluh dan Talaga. Rajagaluh diabadikan dalam naskah-naskah tersebut dengan eksistensi sesosok pemimpin nonmuslim bernama Arya Kiban yang menantang kekuasaan Sunan Gunung Jati, sementara Talaga dituliskan sebagai benteng terakhir kekuasaan pra-Islam yang tidak menginginkan kedatangan agama baru di tanah Sunda. Walaupun sebelumnya dua daerah itu sangat sulit ditaklukkan, pada akhirnya para utusan-utusan kerajaan Islam dari daerah pesisir tersebut berhasil memasuki wilayah itu 
dengan sangat baik dan kemudian menyebarkan nilai-nilai Islam. Setelah itu, proses Islamisasi di daerah Majalengka menjadi relatif lebih mudah dilakukan. Terlebih lagi, pemimpin-pemimpin lokal pun satu persatu memeluk agama Islam yang selanjutnya semakin mempermudah kegiatan dakwah di daerah yang bertanah subur itu.

Garis sejarah yang telah panjang itu ternyata tidak selurus dan sejelas yang dipikirkan. Meskipun secara garis besar perjalanan sejarahnya telah diketahui, namun sisi-sisi spesifiknya belum terlalu jelas sehingga dalam konteks ini memerlukan penelaahan yang lebih dalam agar diketemukan fakta-fakta baru yang bisa membuat titik-titik sejarah yang masih gelap dan tertutupi kabut masa yang pekat menjadi terang benderang dan jelas dilihat.

Salah satu cara yang bisa dilakukan untuk mengungkap tabir itu adalah dengan melakukan penelitian arkeologi, yang dalam tulisan ini objeknya adalah makam tokoh-tokoh penting penyebar Islam di Majalengka. Dilihat secara objektif, makam merupakan peninggalan masa lalu yang pada umumnya memiliki kekhasan dan ciri unik tersendiri. Salah satu makam yang banyak dikunjungi dan diingat oleh masyarakat sebagai tempat peristirahatan sosok penting kegiatan Islamisasi di daerah Majalengka adalah makam dari seorang syaikh masyhur yang bernama K.H. Tubagus Latifuddin yang terletak di Desa Pageraji, Kecamatan Maja.

\section{B. Gambaran Umum Wilayah}

1. Kondisi Alam Majalengka dan Pageraji

Kabupaten

Majalengka merupakan salah satu kabupaten di Jawa Barat yang lokasinya mencakup wilayah Gunung Ciremai bersama Kabupaten Kuningan. Di sebelah utara kabupaten, terhampar dataran rendah yang kontur tanahnya cukup landai sehingga kemudian dijadikan sebagai lokasi untuk pembangunan Bandara Internasional Jawa Barat Kertajati. Sementara bagian tengah wilayah ini memiliki kontur perbukitan yang sangat bervariasi meskipun ada pula dataran yang cukup rendah. Sedangkan untuk wilayah selatan kabupaten, berdiri tegak gunung-gunung dengan titik tertingginya, yaitu puncak Gunung Ciremai. Di samping itu, di sisi barat daya bertengger Gunung Cakrabuana yang menjadi tapal batas wilayah Majalengka bersama Kabupaten 
Tasikmalaya dan Kabupaten

Sumedang.

Kabupaten ini terletak pada titik koordinat $108^{\circ} 03^{\prime}-108^{\circ} 19$ Bujur Timur hingga $108^{\circ} 12^{\prime}-108^{\circ} 25$ Bujur Timur (dihitung dari barat ke timur), dan $6^{\circ} 36^{\prime}-5^{\circ} 58$ Lintang Selatan hingga $6^{\circ} 43^{\prime}-7^{\circ} 44$ (dari utara ke selatan).

Dari sisi administrasi, Majalengka berbatasan dengan 6 (enam) kabupaten, yaitu Kabupaten Kuningan dan Kabupaten Cirebon di sisi timur, Kabupaten Tasikmalaya dan Kabupaten Ciamis di sebelah selatan, Kabupaten Sumedang di sisi barat, dan Kabupaten Indramayu di sisi utaranya.

Desa Pageraji sendiri merupakan salah satu desa yang berada di Kecamatan Maja, sebuah kecamatan yang letaknya di arah selatan Kabupaten Majalengka. Letak desa ini di sebelah tenggara dari ibu kota kabupaten Majalengka dengan jarak sekitar $20 \mathrm{Km}$ yang bisa ditempuh dalam jangka waktu 0,5 jam perjalanan jika menggunakan angkutan umum.

Secara geografis, kontur fisik Desa Pageraji berbukit yang bervariasi dengan dataran-dataran landai. Jika dilihat dari ketinggiannya, maka desa ini termasuk dataran sedang karena memiliki tinggi di atas $400 \mathrm{mdpl}$ dan bersuhu dalam kisaran $15^{\circ}-25^{\circ} \mathrm{C}$, dengan curah hujan sekitar 136 hari/tahun.

Tak pelak, kondisi itu membuat tanah di desa yang berada di bawah kaki Gunung Bongkok tersebut sangat subur dan amat cocok untuk ditanami oleh padi, pelbagai tumbuhan kedua atau palawija, serta tanaman-tanaman holtikultura lainnya. Karena sumber air di Pageraji amat melimpah, wilayah itu juga sangat potensial untuk pengembangan peternakan dan perikanan.

Desa yang hanya memiliki dua dusun (yaitu Dusun Singajaya dan Dusun Jagaraksa) ini, berada tidak jauh dari jalan raya yang menghubungkan Kecamatan Sukahaji dengan Kecamatan Maja. Menurut Tatang Manguny, jalur ini merupakan jalan raya utama Maja-Cirebon pada masanya. Dari kantor bupati (sebelum tahun 1840) yang berada di Maja, jalan itu mengarah ke utara, lalu belok melintasi jembatan Cirungkut (Cibuni) yang selanjutnya melewati Cileungsi Paniis, lalu ke Cicalung, Ciomas, Padahanten, Sukahaji, mengarah ke timur yaitu ke Rajagaluh, Leuwimunding, Banjaran, selanjutnya ke Palimanan, arah ke Plumbon, hingga 
akhirnya sampai ke Cirebon. ${ }^{4}$ Jika benar demikian, maka lokasi Desa Pageraji tidak jauh dari akses jalan vital saat itu, sehingga tidak mengherankan apabila benar ditemukan banyak peninggalan masa lalu.

Bagaimanapun, kepemilikan letak strategis itu akan mendorong geliat ekonomi untuk berkembang karena akses dari pusat lahan (produksi) tradisional masyarakat mudah dijangkau sehingga memudahkan perjalanan hasil tani dan keterampilan masyarakat ke pasar yang biasanya terletak di kota pusat distrik dan juga kota kabupaten.

2. Sejarah Singkat Maja dan Majalengka

Maja dan Majalengka adalah dua nama yang ternyata memiliki banyak perbedaan di samping sejumlah persamaan yang dimiliki keduanya. Perbedaannya, kedua daerah ini dalam konteks kekinian mempunyai status administratif yang berbeda. Jika Maja hanya sebagai kecamatan, maka Majalengka telah tercatat sebagai sebuah kabupaten. Selain itu, kontur kedua daerah ini juga sangat berbeda

4 Tatang Manguny, Maja dan Majalengka Jaman Baheula,

https://tatangmanguny.wordpress.com/sejarahkabupaten-majalengka-bunga-rampai/madja-danargalingga-jaman-baheula/, diakses pada 12 Juni 2017. karena Maja termasuk dataran sedang yang juga dihiasi banyak bukit karena lebih dekat dengan Gunung Ciremai sedangkan Majalengka untuk datarannya lebih rendah dan termasuk wilayah yang landai. Adapun kesamaan yang dimiliki keduanya adalah samasama pernah jadi ibukota kabupaten, bahkan nama keduanya juga pernah tertulis sebagai nama kabupaten. Namun, yang kini eksis sebagai kabupaten adalah Maja.

Menurut tradisi lisan yang berkembang di tengah masyarakat, nama Maja dan Majalengka dipercayai berasal dari kisah tentang Pangeran Muhammad yang mencari obat untuk menyembuhkan wabah penyakit di Cirebon. Konon, penyembuhnya adalah buah Maja yang dimiliki oleh Nyi Rambut Kasih. Namun karena adanya sejumlah masalah, Nyi Rambut Kasih tidak mau menyerahkan buah itu sehingga kemudian terjadilah peperangan. Dalam pertempuran itu, sang nyai menghilang bersama buah maja dan Pangeran Muhammad berkata, "maja e langka" atau "buah majanya tidak ada." Cerita Pangeran Muhammad tersebut juga diyakini sebagai kisah upaya Islamisasi di Majalengka dan terjadi pada 10 Muharam 1412 tahun Hijriah, yang 
dalam tahun Masehi jatuh pada tanggal 7 Juni $1490 .{ }^{5}$ Meski kemudian tanggal ini ditetapkan menjadi hari jadi Majalengka, ternyata masih menyisakan banyak polemik dan kontroversi.

Pada masa selanjutnya, Maja berkembang menjadi sebuah daerah yang sangat ramai karena memiliki lahan yang subur dan mudah ditanami pelbagai macam tumbuhan yang dijadikan sebagai penyokong utama nadi kehidupan di masa lalu. Pada saat Cirebon sudah tidak sekuat di zaman Syarif Hidayatullah, pengaruh Mataram masuk ke bumi Priangan. Pada masa Sultan Agung, wilayah yang dikuasai oleh kerajaan pedalaman itu sangat lah luas. Dalam naskah Pulosaren, tercatat bahwa pengaruh Mataram itu sangat luas dan mencakup ratusan wilayah setingkat kabupaten.

"Bawahan Mataram adalah 140 kabupaten, semua itu tidak termasuk (dengan daerah-daerah lain) yang berada di wilayah pesisir," tulis Shafiyuddin dalam naskah yang telah diterbitkan itu. ${ }^{6}$

\footnotetext{
5 Mengenai cerita rakyat ini, lihat lebih lanjut, $\mathrm{N}$. Kartika, Sejarah Majalengka: Dari Talaga, Maja, Sindangkasih Hingga Majalengka, (Jatinangor: Uvula Press, 2007).

${ }^{6}$ Haji Muhammad Shafiyuddin, Sajarah Carub Kandha: Naskah Pulosaren, Bambang Irianto (ed.), Muhamad Mukhtar Zaedin dan Tarka
}

Ketika VOC berhasil merebut tanah Priangan dari genggaman Mataram, wilayah di sekitar lereng Gunung Ciremai tetap berada di bawah kendali raja-raja Cirebon. $^{7}$ Namun memang karena adanya sejumlah pergeseran kekuasaan yang mengakibatkan terpecahnya Cirebon menjadi beberapa kesultanan, maka wilayahnya pun dibagi ke dalam beberapa penguasa. ${ }^{8}$ Pada masa itu, Majalengka termasuk ke dalam wilayah Kesultanan Kanoman.

Memasuki abad ke-19, wilayah Cirebon tidak pernah berhenti dari masalah. Sejumlah konflik yang hadir, baik itu yang sifatnya vertikal maupun horizontal, terus terjadi dan berlarutlarut. Tidak ada pemimpin kolonial yang berani mengambil tindakan tegas di daerah ini, karena mereka sadar bahwa pemerintahan yang mereka bangun pun belum sekuat yang mereka harapkan.

Ketika konflik di Eropa semakin jelas arah dan alur akhirnya, maka

Sutaraharja (alih bahasa), (Yogyakarta: Penerbit Deepublish, 2017), hlm. 550.

Wilayah yang dimaksud adalah Cirebon, Kuningan, Majalengka, dan Indramayu, saat ini. Dulu, Galuh juga termasuk ke dalam wilayah Cirebon sebelum kemudian dimasukkan ke dalam kelompok daerah Priangan oleh Belanda.

8 Baca, Adeng, dkk., Kota Dagang Cirebon Sebagai Bandar Jalur Sutra, (Jakarta: Departemen Pendidikan dan Kebudayaan RI, 1998). 
pemimpin kolonial di Jawa pun semakin mantap untuk melakukan reorganisasi wilayah guna mengamankan kepentingan dan daerah yang mereka kuasai. Pemimpin Batavia yang berani melakukan hal itu adalah Herman Wilhelm Deandels (m. 18081811).

Langkah berani pertama yang dilakukannya adalah menghapuskan kekuasaan para penguasa Cirebon dan memecah wilayahnya ke dalam beberapa bagian yang bisa dipantau secara langsung. Ia merubah struktur pemerintahan tanah koloni dan melakukan reorganisasi wilayah, termasuk salah satunya wilayah Cirebon yang menjadi Landdrostambt der Kesultanan en Cheribonsche Preanger-Reggentschappen.. Daerah ini pada saat itu dibentuk sebagai salah satu landdrostambt di Jawa bagian barat, di samping Landdrostambt der Jacatrasche en PreangerReggentschappen. ${ }^{9}$ Pada masa itu, keberadaan kesultanan yang ada masih diakui oleh Deandels walaupun kekuasaannya sudah menjadi sangat terbatas.

J.A. van der Chijs, Nederlandsch-Indisch Plakaatboek, 1602-1811, (Batavia: Landsdrukkerij 's Hage Martinus Nijhoff, 1896), hal. 474-475; 568-569.
Peraturan tegas Daendels untuk daerah Cirebon itu dibakukan ke dalam ketentuan yang khusus dan dikeluarkan pada tanggal 2 Februari 1809. Peraturan yang tertulis sebagai Reglement op het Beheer van de Cheribonsche Landen (Peraturan Pemerintahan di Wilayah Cirebon) itu menetapkan pencabutan kekuasaan politis Sultan Kasepuhan, Sultan Kanoman dan Sultan Kacirebonan. Mereka pun hanya memiliki kedudukan derajat yang sama dengan para bupati (regent) yang menjadi para pegawai pemerintahan kolonial.

Meskipun begitu, pihak Batavia tetap sadar bahwa Cirebon itu adalah tanah panas yang rentan akan konflik. Jangankan karena berakar dari hal-hal yang berbau asing, karena masalah kekeluargaan pun daerah itu bisa terbakar dalam konflik. Oleh karenanya, untuk meredam kemungkinan konflik, Daendels memberikan kebijakan yang tetap atas wilayah kekuasaan para Sultan Cirebon pada tanggal 13 Maret 1809. Wilayahwilayah itu dibagi dengan satuan ukuran yang berlaku pada saat itu, yaitu satuan junk. Dan 1 jung itu sama dengan 4 bau. Sedangkan 1 bau itu ukurannya adalah sama dengan 500 tumbak atau sekitar 7.000 meter 
persegi. Jadi, apabila dikalkulasikan dengan satuan meter persegi yang banyak dipakai saat ini, maka 1 jung adalah 28.000 meter persegi. ${ }^{10}$

Adapun wilayah-wilayah para sultan Cirebon yang telah dibagi Batavia itu adalah sebagai berikut:

1. Area seluas 4239 junk atau 8478 ribu roe persegi, yang tersebar di daerah Kuningan, Talaga, Gebang, Losari, dan serta sebagian daerah Cirebon, dipercayakan oleh Daendels kepada Pangeran Tajul Arifin Johanudin, sebagai Sultan Sepuh VII, yang bertahta di Kraton Kesultanan Kasepuhan. Wilayah itu cukup banyak dihuni masyarakat karena ditinggali oleh sekitar 80.739 jiwa manusia. Daendels memberi ketetapan durasi kekuasaan atas wilayah ini selama 25 tahun;

2. Sedangkan area yang lebih luas, yaitu wilayah seluas 4304 junk atau setara dengan 8608 ribu roe persegi, yang meliputi daerah Panjalu,

10 Untuk masalah satuan ukuran yang lebih jelas, lihat, Purwadi \& Purnomo, 2008: 61; Wijayati, 2001: xiv.
Majalengka, Rajagaluh, Sindangkasih, Matangaji, dan sebagian daerah Cirebon, diberikan otoritasnya oleh Daendels kepada Pangeran Raja Mohammad Komarudin I sebagai Sultan Anom VI, yang saat itu tengah menjadi pemimpin tertinggi Kraton Kesultanan Kanoman. Wilayah yang dihuni oleh 76.622 jiwa ini diberi mandat kekuasaannya hanya dalam jangka waktu 27 tahun;

3. Di sisi yang lain, area yang tidak kalah luasnya juga diamanatkan kepada Sultan Kacirebonan. Tidak tanggung-tanggung, tanah itu luasnya hingga 4293 junk atau 8586 ribu roe persegi, yang mencakup 5 wilayah, yaitu sebagian daerah Cirebon, sebagian Bengawan Wetan, Bengawan Kulon yang posisinya di sebelah barat Sungai Cimanuk, daerah Kandanghaur, dan Indramayu.

Wilayah yang dihuni oleh 80.250 jiwa itu hanya diberi wewenang dan dalam jangka 
waktu yang cukup singkat, yaitu enam tahun saja. ${ }^{11}$

Jika melihat uraian tersebut, maka dapat diketahui bahwa di masa kolonial, ketika Cirebon masih diberi mandat kekuasaan, Majalengka termasuk ke dalam wilayah yang dikuasai oleh Kesultanan Kanoman. Dengan demikian, tidak mengherankan apabila dalam waktu-waktu selanjutnya selalu banyak bermunculan tokohtokoh Majalengka yang memiliki darah Cirebon yang afiliasinya dengan Kesultanan Kanoman. Pada umumnya, selain karena mendapat dawuh atau surat perintah dari pihak penguasa, baik itu Keraton maupun pemerintah kolonial, untuk melakukan tugas-tugas tertentu, banyak juga dari orang-orang Cirebon yang berkelana ke daerahdaerah yang ada di Majalengka guna menyebarkan Islam ke pelbagai lapisan kelompok masyarakat. Sebagian besar

\footnotetext{
11 J.A. van der Chijs, ...., hal. 568-569. Selain turut membagi-bagi wilayah yang sebenarnya telah melangkahi wewenang para tetua adat dan penguasa Cirebon tersebut, Daendels juga menggariskan satu hal penting yang mengindikasikan bahwa Cirebon telah benar-benar tunduk pada kekuasaan asing, yaitu penyerahan wajib upeti atau pajak. Pada saat itu, ketiga sultan yang ada di Cirebon diharuskan untuk menyerahkan beras yang sangat banyak, yakni 2.000 koyan (dengan hitungan 1 koyan sebesar 1.853 kilogram) setiap tahunnya. Selain itu, mereka juga diharuskan membayar pengakuan utang sebesar 30.000 ringgit tiap tahun, sungguh jumlah yang sangat banyak. Lihat lebih lanjut, Atja, 1988, hal. 43.
}

dari mereka kemudian menetap dan tinggal disana hingga menurunkan generasi Islam secara turun temurun.

Kedekatan antara daerah Majalengka dengan Kanoman juga dibuktikan dalam peristiwa perang panjang Bagus Rangin. Selain berusaha untuk menegakkan hak-hak sipil dan melepaskan diri dari jerat pajak yang sangat mencekik, pemimpin perlawanan di Jatitujuh itu juga berupaya untuk menundukkan Kanoman. Dalam naskah Keraton Kacirebonan, keinginan Bagus Rangin itu dituliskan: ${ }^{12}$

"Brandal Rangin panyeleke anggunturi / Duga ara / Obar Praja Pakung Wati / Sengge padha muri jeng raja Kanoman." Yang artinya: "Berandal (Ki Bagus) Rangin menyerbu memberontak Praja Pakungwati (Cirebon), ia bertekad ingin menduduki Kanoman."

Berhubungan dengan pembahasan mengenai diaspora tokohtokoh asal Kanoman Cirebon tersebut, tokoh penyebar Islam yang dibahas dalam tulisan ini pun, yaitu K.H. Tubagus Latifuddin, ternyata memiliki garis darah yang juga berhubungan

\footnotetext{
${ }^{12}$ Bambang Irianto dan Tarka Sutaraharja, Sejarah Cirebon: Naskah Keraton Kacirebonan, (Yogyakarta: Deepublish, 2013), hlm. 58 dan 134.
} 
langsung dengan salah satu pusat kekuasaan kultural di Cirebon, yaitu Keraton Kanoman. ${ }^{13}$ Dalam konteks politik dan kekuasaan, Kanoman pernah menjadi gusti dari wilayah yang semula daerah Kerajaan Sunda Galuh.

\section{C.Struktur Makam K.H. Tubagus Latifuddin}

\section{Struktur Makam}

Makam seorang syekh yang terkenal sebagai salah satu penyebar Islam di Majalengka ini terletak di Blok Pasantren (juga dikenal sebagai Dusun Singajaya), Desa Pageraji, Kecamatan Maja dan berada di sebuah areal pemakaman desa yang dikelilingi oleh sawah-sawah di sisi barat dan selatan serta pemukiman warga di sebelah utara dan timur areal. Karena pamor makam kyai ini sangat tinggi, areal pemakaman ini juga disebut sebagai pemakaman Eyang Latifuddin atau juga pemakaman Blok Pasantren sesuai dengan nama kawasan di sebelahnya. Penisbatan tersebut menunjukkan bahwa sosok penting penyebar Islam di Majalengka ini adalah tokoh yang sangat terkenal dan memiliki jasa yang tidak sedikit bagi

13 Wawancara dengan Ridwan, keturunan K.H. Tubagus Latifuddin yang berperan sebagai penjaga kompleks makam tersebut, 28 Juli Agustus 2016, pukul 10.16 WIB. kehidupan sosial dan beragama masyarakat. Situs ini berada pada posisi 06 52 '09.0” LS dan 108 18'18.4" BT dengan ketinggian 489 mdpl. Dengan kondisi dan suasana ketinggian tersebut, iklim daerah Pageraji termasuk yang sejuk dan cukup dingin ketika malam tiba. Terlebih lokasinya tidak jauh dari Gunung Ciremai, gunung tertinggi di wilayah Jawa Barat, yang memiliki alur perjalanan sejarah yang amat panjang.

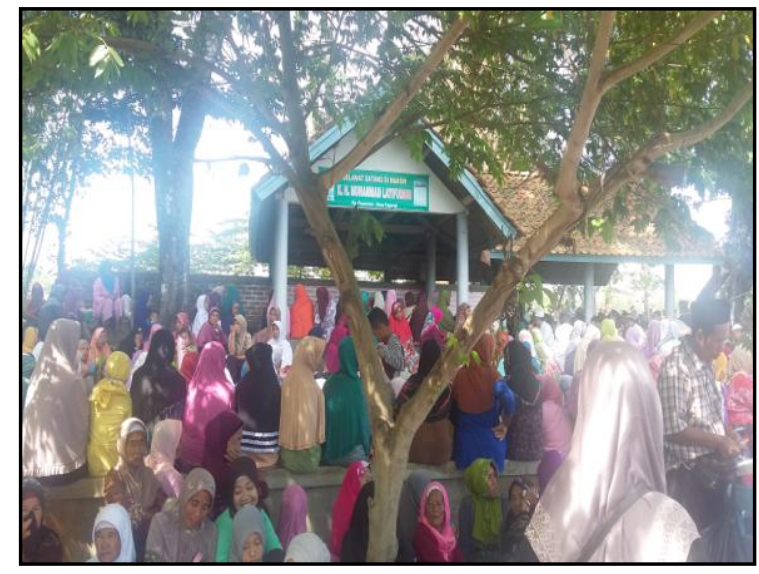

Gambar 1. Makam Syekh K.H. Tubagus Latifuddin (Sumber: Dokumen pribadi, 2016)

Makam yang berbatasan dengan kawasan dayeuh Pageraji di sisi utara, Desa Cicalung di sebelah barat, Desa Paniis di sisi selatan, dan dengan Gunung Bongkok di sebelah timur ini berorientasi utara-selatan.

Jirat dari makam ini berupa susunan batu bata dengan denah berbentuk persegi panjang yang 
memiliki empat sisi yang berbeda. Terdapat 3 (tiga) tingkatan dalam jirat makam ulama yang masih keturunan dari Syekh Abdul Muhyi Pamijahan ini. Untuk tingkat pertama (atau yang paling bawah), panjangnya adalah 266 $\mathrm{cm}$, lebarnya $152 \mathrm{~cm}$, dan tinggi $24 \mathrm{~cm}$. Sedangkan tingkat yang kedua (atau yang berada di tengah-tengah), panjangnya adalah $241 \mathrm{~cm}$, memiliki lebar $126 \mathrm{~cm}$, dan tinggi $12 \mathrm{~cm}$. Sementara tingkat ketiga (atau yang paling atas) panjangnya $215 \mathrm{~cm}$, lebarnya $101 \mathrm{~cm}$, dan tingginya sekitar $10-11 \mathrm{~cm}$.

Batu nisan dari tempat peristirahatan seorang muballigh besar ini terbuat dari batu alam, dengan jenis yang cenderung lebih baru ketimbang makam aslinya. Dalam keterangan keturunan sang kyai, diketahui bahwa batu nisan ini baru karena memang makam pernah direstorasi oleh keluarga beberapa tahun sebelumnya. Dalam keterangannya, diketahui bahwa pada mulanya nisan makam itu hanya berbentuk dari bahan material batu sederhana. ${ }^{14}$ Terdapat dua batu nisan di makam ini, dengan jarak antara satu nisan dengan nisan yang lain adalah $158,5 \mathrm{~cm}$.

\footnotetext{
14 Wawancara dengan Ridwan, ...., 28 Juli
} Agustus 2016, pukul 10.16 WIB.
Pembuatan nisan makam pada masa lampau, memang sebagian besar dilakukan dengan memanfaatkan bahan baku yang ada di dekat lokasi makam. Hal itu lebih mudah dilakukan, ketimbang mencari bahan baku yang memang asal muasalnya jauh dari lokasi penguburan, meskipun bahan baku yang dimaksud itu lebih baik kualitas dan daya tahannya. Makam dengan lokasi di dataran tinggi atau pegunungan, pasti akan lebih memakai bebatuan yang banyak tersedia disana, seperti batu kali ataupun batu andesit. Sementara itu di dataran rendah atau yang lokasinya dekat dengan bibir pantai, maka akan lebih banyak dibuat dari batu-batu karang nisan pemakamannya karena memang tersedia dalam jumlah yang sangat banyak di daerah tersebut. Sedangkan untuk dataran yang menengah dengan kondisi alam yang banyak ditumbuhi dengan pepohonan, pasti akan lebih banyak memanfaatkan kayu yang melimpah disana sebagai bahan baku pembuatan nisan. Adapun lokasi Pageraji yang memang berada di daerah perbukitan dengan lokasi yang tidak jauh dari sungai-sungai yang menyediakan banyak bebatuan, membuat makam-makam disana 
banyak terbuat nisannya dari batu-batu yang disebutkan tadi.

Di samping cara pandang kajian dengan aspek lokasi itu, jenis makam juga dapat dilihat dari aspek penyusunan bahan baku. Dengan dasar dan data makam yang tersebar di wilayah Indonesia, Ambary mengelompokkan makam-makam berdasarkan bahan makam (nisan) ke dalam 3 (tiga) jenis, yaitu makam dengan bahan kayu (jati, unglen, besi, dll), makam dengan bahan batu (andesit, kapur, pasir, granit, marmer, dll), dan makam dengan penyusunan bahan yang berasal dari logam (kuningan, perunggu, dll). ${ }^{15}$

Di depan makam terdapat bangunan pelindung yang berupa cungkup namun tidak full bangunan. Bentuknya hanya bangunan setengah permanen yang bertembok semen dengan susunan batu bata dan beratapkan genteng berjenis genteng palentong. Terdapat beberapa tiang berbentuk bulat memanjang ke atas yang menjadi penyangga bangunan yang berada di tengah komplek pemakaman ini. Bangunan setengah permanen tersebut sebenarnya tidak

15 Hasan Muarif Ambary, Menemukan Peradaban Arkeologi dan Islam di Indonesia, (Jakarta: Pusat Penelitian Arkeologi Nasional. Jakarta: Logos Wacana Ilmu, 1998), hlm. 18. menutupi ataupun melindungi makam, namun lebih berkesan untuk melindungi para ziarah dari kondisi cuaca, terik matahari, ataupun hujan yang memang sering terjadi jika musim penghujan di wilayah yang berada di bawah kaki Gunung Bongkok yang terangkai dengan Gunung Ciremai ini.

2. Tradisi di Makam K.H. Tubagus Latifuddin

Di makam ini, ada satu tradisi rutin yang memang dikelola secara teratur oleh keluarga dalam bentuk acara haol (haolan). Acara yang bertujuan untuk mendoakan arwah leluhur agar diterangkan kuburnya itu biasanya dilakukan setahun sekali, yang waktunya ditentukan setelah lebaran Idul Fitri. Di samping itu, ada pula tradisi lain yang memang bersifat personal, dengan tujuan khusus tertentu. Kedua hal itu dibedakan oleh motivasi yang mendasari kedatangan mereka ke kompleks pemakaman.

Dari pengamatan yang telah dilakukan, diketahui pula bahwa ada berbagai macam pemaknaan mengenai tradisi ziarah di makam ini. Sebagaimana disebutkan di atas, pemaknaan itu berjalan seiringan dengan motivasi dan tujuan utama yang diinginkan. 
Kondisi semacam itu, tidak hanya terjadi di tengah masyarakat Sunda Majalengka saja, namun juga di dalam kelompok suku lainnya. Dalam konteks masyarakat Jawa misalnya, di dalam aspek kehidupannya, ternyata masih sangat berpatokan terhadap aturan dan larangan yang ujung pangkal sumbernya ada dalam tiga nilai dominan yang menjadi acuan di dalam kehidupan. Pertama, nilai kolektivisme, yaitu nilai yang mengedepankan kebersamaan di dalam kehidupan bermasyarakat. Kedua, nilai spritualisme atau nilai yang berkaitan dengan aspek kerohanian manusia. Bagaimanapun, aspek-aspek spiritual memang menjadi salah satu hal yang penting dalam diri manusia. Ketiga, nilai kemanusiaan, yaitu nilai yang berhubungan dengan jiwa humanisme dan perasaan tenggang rasa. ${ }^{16}$ Semua nilai tersebut ada dan dapat terlihat dari tindakan dan perilaku manusia, meski memang tidak selalu terwujud dalam satu nilai saja melainkan dua atau bahkan hingga tiga nilai secara bersama-sama. Aspek-aspek nilai yang telah disebutkan itu dapat dianalisa sebagai cara pandang pemaknaan

16 Iman Budhi Santosa, Laku Prihatin: Investasi Menuju Sukses Ala Manusia Jawa, (Yogyakarta: Memayu Publising, 2011), hlm. 13. masyarakat atas kebiasaan untuk datang dan berdo'a di makam Syekh K.H. Tubagus Latifuddin tersebut.

Pemaknaan yang positif umumnya dijalankan oleh mereka yang datang ke makam dengan tujuan mendo'akan keselamatan sang kyai di alam kubur. Perilaku yang pertama ini dilakukan oleh para keturunannya dan juga para pengagum sang ulama yang telah memiliki jasa bagi pengembangan Islam di tanah Majalengka. Karena hal itu pula, makam tersebut mendapat perlakuan yang khusus dari keluarga dan masyarakat, baik itu masyarakat sekitar maupun masyarakat yang datang dari luar daerah. Dalam studi Ambary, diketahui bahwa perlakuan semacam itu bisa ada karena terdapat emosi keyakinan dan kepercayaan tertentu dalam diri manusia sehingga objek-objek yang dimaksud dianggap sakral meskipun pada dasarnya bersifat profan. $^{17}$

$\begin{array}{lrr}\text { Hal-hal } & \text { yang } & \text { demikian } \\ \text { menunjukkan } & \text { adanya suatu } \\ \text { peninggalan masa pra-Islam yang } & \text { yan } \\ \text { masih dianut oleh masyarakat. Perilaku } \\ \text { itu menunjukkan adanya asimilasi yang }\end{array}$

17 Baca lebih lanjut, Hasan Muarif Ambary, "Makam-makam Kesultanan dan Parawali Penyebar Islam di Pulau Jawa," Dalam Aspekaspek Arkeologi Indonesia No. 12. (Jakarta: Pusat Penelitian Arkeologi Nasional, 1991). 
amat jelas karena masyarakat melakukan perlakuan khusus tertentu terhadap makam dari tokoh-tokoh besar (seperti halnya makam para raja, pembesar, pemuka agama, atau pendiri daerah atau desa) tersebut.

Mengenai pengkultusan makam tersebut, Hasan M. Ambary menguraikan bahwa hal itu merupakan tradisi yang ada di sebagian besar masyarakat Muslim yang telah tersebar di wilayah Nusantara, khususnya di Pulau Jawa. Kubur yang mendapat perlakuan sebagai objek yang sakral seperti itu, terkadang menjadi tempat yang secara keliru diyakini sebagai media untuk ngalap berkah atau meminta sesuatu. ${ }^{18}$ Tentunya, ajaran Islam tidak pernah menunjukkan adanya ritual atau upacara-upacara peringatan kematian di luar prosesi baku dalam perawatan jenazah sampai pemakaman yang telah termaktub secara teratur dengan jelas dalam ajarannya. Namun dalam konteks Indonesia, ternyata timbul pelbagai peringatan kematian dalam hari-hari tertentu, seperti dalam hari ketiga, ketujuh, keempat puluh, keseratus dan keseribu hari yang sebetulnya berasal dari adat dan tradisi yang berkembang

18 Hasan Muarif Ambary, Menemukan Peradaban ...., hlm. 43. sebelum adanya Islam. Aktivitas haol dan ziarah kubur pada hakikatnya merupakan bentuk modifikasi dari budaya megalitik yang berkembang secara luas pada masa pra-sejarah. Menurut informasi yang berasal dari masyarakat sekitar, diketahui bahwa acara haol yang dihadiri oleh pelbagai lapisan masyarakat dari banyak daerah itu rutin dilaksanakan setahun sekali di kompleks pemakaman.

Sedangkan pemaknaan yang berkonotasi negatif, dilakukan oleh mereka yang memiliki tujuan pribadi ketika datang ke makam. Secara umum, tujuan-tujuan yang kurang baik itu adalah guna mengejar hal-hal yang bersifat duniawi, seperti masalah harta, kedudukan, dan pengasihan-pengasihan lainnya.

Kondisi makam sebagai objek ziarah dengan tujuan permintaan khusus tertentu itu menunjukkan bahwa makam seakan berada dalam konteks abstrak dan unik dari sistem perilaku manusia. Pelbagai ritual, seperti membersihkan makam, menaburi bunga, memegang bagian makam tertentu, memberi wewangian, yang dilakukan dalam hari-hari dengan hitungan tertentu, diyakini menjadi media penghubung antara masyarakat dengan sosok tokoh yang ada. Pada 
saat itulah, permintaan-permintaan diajukan. Sudewo mengungkapkan bahwa di titik itu, mereka tengah memohon kepada Allah dengan melalui perantara sesuatu. ${ }^{19}$

Dalam konteks yang kedua ini, pihak keluarga sudah jelas-jelas melarang dan menghimbau agar ziarah di makam K.H. Tubagus Latifuddin tersebut tidak dijadikan sebagai ajang kemusyrikan. Namun tetap saja, ada beberapa orang tertentu yang menganggap ketentuan yang diberikan oleh para keturunan sang kyai itu sebagai angin lalu dan tidak mengindahkannya sama sekali.

\section{Peran K.H. Tubagus Latifuddin} dalam Proses Islamisasi Majalengka

Upaya masuknya Islam ke Majalengka tidak terjadi dengan mudah sebagaimana membalikkan telapak tangan. Terdapat jangka waktu yang cukup lama untuk menancapkan agama Ilahi di daerah yang semula berperan sebagai vassal Kerajaan Sunda Pajajaran tersebut.

Di samping itu, kedatangan Islam di Majalengka juga ternyata belum

19 Eri Sudewo, "Pemujaan Kubur : Distorsi atau Retradisionalisasi" dalam Proceedings Analisis Hasil Penelitian Arkeologi I: Religi dalam Kaitannya dengan Kematian, Jilid I, (Jakarta: Pusat Arkeologi Nasional, 1990), hlm. 118-121. dapat ditentukan kepastiannya. Meskipun naskah babad mengerucutkan waktu kedatangan Islam pada tanggal 10 Muharam 1412 tahun Hijriah, yang bertepatan dengan tanggal 7 Juni 1490, namun ternyata belum dapat dipegang secara pasti sebagai dasar pegangan ketetapan mengenai sejarah masuknya Islam ke wilayah Majalengka.

Meskipun Islam telah datang ke Majalengka melalui ekspansi kekuasaan wilayah Cirebon, namun ternyata penyebaran Islam tidak selancar sebagaiman mestinya. Di beberapa tempat, unsur-unsur pra-Islam masih bisa bertahan dan bahkan seakan melakukan resistensi terhadap arah pergerakan Islamisasi. Diterimanya Islam di tengah masyarakat pun ternyata tetap masih berhiaskan aspekaspek yang bersifat sinkretis. Kontak budaya yang terjadi di antara Islam dengan budaya masyarakat setempat menghasilkan dinamika budaya yang unik sehingga kemudian memunculkan akulturasi dan asimilasi budaya.

Dengan latar belakang itu, kemudian pusat-pusat Islam Jawa bagian barat, seperti di Cirebon dan Banten, berupaya mengatasinya dengan mengirimkan para muballigh ataupun ahli agama guna memberikan 
pemahaman yang baik mengenai agama Islam. Dalam hal ini, sosok K.H. Tubagus Latifuddin merupakan seorang ahli agama Islam yang berasal dari garis keturunan kedua pusat Islam yang telah disebutkan sebelumnya. Di samping itu, ia juga memiliki darah Mataram yang berasal dari kakeknya yang berasal dari wilayah Bagelen.

Dari bumi Mataram, sang kyai mendapat darah keturunan penyebar Islam yang sangat masyhur dan bermukim di Pamijahan, yaitu Syekh K.H. Abdul Muhyi. Menurut paparan keluarga, sosok penting bagi perkembangan Islam di Jawa Barat itu merupakan kakek dari K.H. Tubagus Latifuddin karena ayahnya yang bernama K.H. Faqih Ibrahim (yang juga dikenal sebagai Sunan Cipager) itu merupakan putra Syekh K.H. Abdul Muhyi. Hal ini membuktikan bahwa proses Islamisasi melalui proses pernikahan dan keturunan tidaklah sedikit. Apabila kita lihat secara spesifik mengenai paparan babadbabad Jawa sendiri, maka kita akan menemukan bahwa Islamisasi melalui saluran perkawinan itu telah banyak terjadi di antara bangsawan, pedagang, dan ulama. ${ }^{20}$

Sebagai keturunan alim ulama yang menggaungkan Islam di Tatar Pasundan, K.H. Tubagus Latifuddin memiliki tugas mulia yang tidak jauh berbeda dengan para pendahulunya. Setelah belajar Islam dan ilmu agama kepada ayahnya yang jumeneng di daerah Talaga, kemudian Tubagus Latifuddin muda melanjutkan pendidikannya ke beberapa pusat keIslam-an lain di Pulau Jawa dan sekitarnya. Setelah merasa kadar keilmuannya cukup, ia pun kembali kepada ayahnya dan memilih untuk mukim di Pageraji sebagai lahan berdakwahnya.

Kemudian di bawah kaki Gunung Bongkok, ia merintis seruan rohaninya. Selain aktif mendakwahkan Islam kepada penduduk setempat, K.H. Tubagus Latifuddin juga turut mensyiarkan Islam ke sejumlah daerah lain di sekitar Pageraji, Maja, dan Sukahaji, Majalengka.

Dengan bekal ilmu yang mumpuni, banyak orang yang hendak berguru kepada sosok ini. Orang-orang pun banyak berdatangan dari pelbagai tempat ke Pageraji. Lama kelamaan,

\footnotetext{
${ }^{20}$ Marwati Djoened Poesponegoro, Nugroho Notosusanto, Sejarah Nasional Indonesia III, (Jakarta: Balai Pustaka, 1992), hlm. 190-191.
} 
tempat tinggal sang kyai pun semakin ramai oleh kegiatan para muridnya. Karena ramai oleh aktivitas yang berbau Islam itu kemudian dusun yang ditinggali oleh K.H. Tubagus Latifuddin dikenal sebagai Blok Pasantren. Melalui lembaga sosial keagamaan tersebut, dakwah Islam di tanah Majalengka pun semakin ramai dan semarak.

Besarnya penghormatan dan perhatian masyarakat kepada sosok K.H. Tubagus Latifuddin yang telah lama tiada dapat dilihat dari besarnya animo masyarakat terhadap kegiatan yang berhubungan dengan pusara sang kyai. Di samping itu, perlakuanperlakuan khusus terhadap makamnya dapat mempertegas pernyataan tadi. Pada dasarnya, pendirian makam oleh masyarakat memang dilatarbelakangi kepercayaan-kepercayaan atas roh atau benda-benda ghaib dan juga penghormatan atas arwah leluhur. ${ }^{21}$ Kegiatan haol yang dilakukan disana dengan semarak pun semakin mengukuhkan pernyataan tesebut.

Tidak mungkin terjadi suatu kegiatan yang meriah dan semarak, terlebih berkenaan dengan sosok yang

${ }^{21} \quad$ Lihat lebih lanjut, Soekmono, Pengantar Sejarah Kebudayaan Indonesia I, (Yogyakarta: Kanisius, 1981). lama telah meninggal, jika tokoh yang dimaksud bukanlah sosok yang penting dan berperan dalam percaturan sejarah Majalengka. Karenanya dapat disimpulkan bahwa K.H. Tubagus Latifuddin merupakan salah satu tokoh penting yang peran dan kiprahnya perlu diteladani.

\section{E. Penutup}

Dari tulisan sederhana ini, setidaknya ada beberapa poin yang bisa disimpulkan, yaitu:

1) Maja dan Majalengka adalah dua nama daerah yang memiliki perbedaan, baik itu secara sosial, politis, maupun ekonomis. Maja telah ada sejak masa kerajaan-kerajaan tradisional Sunda berdiri, sedangkan Majalengka baru muncul kemudian di zaman kolonial Belanda. Di era kekuasaan asing ini, Majalengka baru berdiri sebagai sebuah kabupaten. Sejak zaman Islam, Majalengka lebih "dekat" dengan Keraton Kanoman Kesultanan Cirebon, sehingga banyak tokoh-tokoh yang berkiprah di Majalengka berasal dari Kanoman. 
2) Makam K.H. Tubagus

Latifuddin terletak di Blok

Pasantren (juga dikenal sebagai

Dusun Singajaya), Desa

Pageraji, Kecamatan Maja,

Majalengka. Pusara tersebut

berada pada posisi $06^{\circ} 52^{\prime} 09.0^{\prime \prime}$

LS dan $108^{\circ} 18^{\prime} 18.4^{\prime \prime}$ BT

dengan ketinggian 489 mdpl.

Jirat dari makam ini berupa

susunan batu bata dengan

denah berbentuk persegi

panjang yang memiliki empat

sisi yang berbeda. Terdapat 3

(tiga) tingkatan dalam jirat

makam ulama yang masih

keturunan dari Syekh Abdul

Muhyi Pamijahan ini. Ukuran

masing-masing tingkatan

bervariasi antara $215 \mathrm{~cm} \mathrm{-} 266$

cm untuk panjangnya, $101 \mathrm{~cm}$ -

$152 \mathrm{~cm}$ untuk lebarnya, dan 10

$\mathrm{cm}-12 \mathrm{~cm}$ untuk tingginya.

Batu nisannya terbuat dari batu

alam, dengan jenis yang baru

karena makam pernah dipugar.

Terdapat bangunan pelindung yang berupa cungkup dalam area makam namun tidak full bangunan.

3) Ada banyak tradisi yang berlangsung di makam ini. Namun semuanya dapat digeneralisir dengan maksud dan tujuannya ke dalam dua macam, yaitu yang bertujuan positif seperti acara ziarah dan haol, serta tradisi dengan tujuan negatif seperti untuk pengajuan permintaan tertentu melalui media hal-hal ghaib disana.

4) Masuknya Islam ke Majalengka tidak terjadi dengan mudah karena sebelumnya banyak yang melakukan resistensi, khususnya dari para pemeluk agama-agama pra-Islam. Kedatangan para muballigh Islam secara bergelombang pada akhirnya semakin membuat daerah ini semakin "hijau" oleh nilai-nilai Islam. Salah satu sosok penting penyebar Islam itu adalah K.H. Tubagus Latifuddin, yang mensyiarkan Islam dari Pageraji, di bawah Gunung Bongkok. Kiprah dan perannya yang sangat besar di masa lalu dibuktikan oleh besarnya penghormatan masyarakat kepada sosok ini, hal itu terlihat dari semaraknya haol memeringati perjuangan sang 
kyai yang dilakukan setiap tahun pada bulan Syawal.

\section{Daftar Pustaka}

Adeng, dkk. 1998. Kota Dagang Cirebon Sebagai Bandar Jalur Sutra. Jakarta: Departemen Pendidikan dan Kebudayaan RI.

Ambary, Hasan Muarif. 1991. Makammakam Kesultanan dan Parawali Penyebar Islam di Pulau Jawa. Dalam Aspek-aspek Arkeologi Indonesia No. 12. Jakarta: Pusat Penelitian Arkeologi Nasional.

Ambary, Hasan Muarif., 1998. Menemukan Peradaban Arkeologi dan Islam di Indonesia. Jakarta: Pusat Penelitian Arkeologi Nasional. Jakarta: Logos Wacana Ilmu.

de Haan, Francois. 1912. Priangan: De Preanger-Regentschappen onder het Nederlandsch bestour tot 1811. Batavia: G. Kolff/Martinus Nijhoff.

Ekadjati, Edi S. 2003. "Sundanese Manuscripts: Their Existence, Functions, and Contents", dalam Journal of the Centre for Documentation \& AreaTranscultural Studies, 2.

Hasbullah, Moeflich. 2011. Sejarah Sosial Intelektual Islam Indonesia. Bandung: Pustaka Setia.

Irianto, Bambang dan Sutaraharja, Tarka. Zaedin, Muhamad Mukhtar dan Darussalam, Panji (eds.). 2013. Sejarah Cirebon: Naskah Keraton Kacirebonan. Yogyakarta: Deepublish.

Kartika, N. 2007. Sejarah Majalengka: Dari Talaga, Maja, Sindangkasih
Hingga Majalengka. Jatinangor: Uvula Press.

Santosa, Iman Budhi. 2011. Laku Prihatin: Investasi Menuju Sukses Ala Manusia Jawa. Yogjakarta: Memayu Publising.

Shafiyuddin, Haji Muhammad. 2017. Bambang Irianto (ed.), Muhamad Mukhtar Zaedin dan Tarka Sutaraharja (alih bahasa). Sajarah Carub Kandha: Naskah Pulosaren. Yogyakarta: Penerbit Deepublish.

Sjamsuddin, Helius, dkk. 1996. Pengantar Ilmu Sejarah. Jakarta: Departemen Pendidikan dan Kebudayaan Direktorat Jenderal Pendidikan Tinggi Proyek Pendidikan Tenaga Akademik.

Soekmono. 1981. Pengantar Sejarah Kebudayaan Indonesia I. Yogyakarta: Kanisius.

Sudewo, Eri, 1990 Pemujaan Kubur : Distorsi atau Retradisionalisasi dalam Proceedings Analisis Hasil Penelitian Arkeologi I. religi dalam Kaitannya dengan Kematian. Jilid I. Jakarta. Pusat Arkeologi Nasional.

van der Chijs, J.A. 1896. Nederlandsch-Indisch

Plakaatboek, 1602-1811, (Batavia: Landsdrukkerij 's Hage Martinus Nijhoff.

Tatang Manguny, Maja dan Majalengka Jaman Baheula, https://tatangmanguny.wordpress. com/sejarah-kabupatenmajalengka-bunga-rampai/madjadan-argalingga-jaman-baheula/, diakses pada 12 Juni 2017. 